\title{
Classification and analysis of guild merchants using smokeless tobacco in Chabahar, Iran, based on the transtheoretical model
}

\author{
Sayed Saeed Mazloomy Mahmoodabad ${ }^{1}$, Iraj Zareban², Mohammad Hossein Fallah Zadeh³, Mohammad Saeed Jadgal*1
}

\section{AFFILIATION:}

1. Social Determinants of Health Research Center, Department Of Health Education and Promotion, School of Public Health, Shahid Sadoughi University of Medical Sciences, Yazd, Iran.

2. Health Promotion Research Center, Zahedan University of Medical Sciences, Zahedan, Iran.

3. Professor, Department of Biostatistics and Epidemiology, School of Health, Shahid Sadoughi University of Medical Sciences, Yazd, Iran.

\section{Article info.}

Received: $20^{\text {th }}$ October, 2018

Accepted: $10^{\text {th }}$ December, 2019

Volume: 9, Issue-1 April, 2019

DOI: https://doi.org/10.3329/updcj.v9i1.41201

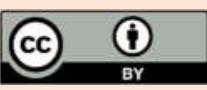

(c) Authors retain copyright and grant the journal right of first publication with the work simultaneously licensed under Creative Commons Attribution License CC - BY 4.0 that allows others to share the work with an acknowledgment of the work's authorship and initial publication in this journal.

https://creativecommons.org/licenses/by/4.0/

Publisher: Update Dental College, Dhaka, Bangladesh

Web: www.updatedentalcollege.edu.bd

E-mail: updcj@hotmail.com

\author{
* Corresponding Author \\ Mohammad Saeed Jadgal \\ Social Determinants of Health Research Center, Department Of Health \\ Education and Promotion, School of Public Health, Shahid Sadoughi \\ University of Medical Sciences, Yazd, Iran. \\ Email:kh_jadgal@yahoo.com
}

\begin{abstract}
Introduction: The use of all types of smokeless tobacco poses a serious risk to the health of community members. The present study was conducted to classify the guild merchants using smokeless tobacco in Chabahar, Iran, based on the Trans-Theoretical Model (TTM) and then analyze the relationships between the examined variables based on the constructs of this model.

Materials and Methods: This descriptive cross-sectional study was conducted on 320 merchants working in different guilds in Chabahar in 2018, who were selected through simple random sampling. The data collection tool was a researcher-made questionnaire with a demographic and background information section, behavioral items and items on the constructs of the transtheoretical model, and was used after its validity and reliability were confirmed. Data were analyzed in SPSS software using statistical tests such as mean and SD, the Chi-square test, the ANOVA and Tukey's test.

Findings: Most of the participants in the study were in the age group of 20-30 years (69\%). Hairdressers and textile stores (19\%) were the largest and hotel and restaurant businesses (2\%) the smallest trade guilds in this study. Most people in the study consumed Gutkha (24\%). A total of $85 \%$ of the subjects were in the precontemplation stage, $12.5 \%$ in the contemplation stage and $2.5 \%$ in the preparation stage, and the stages of change had a significant difference with constructs including counter-conditioning, self-liberation, decisional balance and temptation to use tobacco $(P<0.05)$.

Conclusion: Since most merchants were in the precontemplation stage, and given their age and the proven harms of smokeless tobacco, interventions to encourage these people to quit tobacco consumption using the TTM constructs are necessary.
\end{abstract}

\section{Keywords:}

Transtheoretical Model, Smokeless Tobacco, Guilds.

Introduction:

The term smokeless tobacco refers to the use of unburned tobacco in the form of chewing, spitting, dipping and snuffing (1). Nearly 28 chemical substances in smokeless tobacco have a carcinogenic nature -most notably nitrosamine (1). Many people who use smokeless tobacco may think that consuming these products is safer than smoking cigarettes, but all smokeless tobacco products contain toxic substances, and the use of smokeless tobacco poses a serious health risk (2). The use of smokeless tobacco products increases the risk of tooth decay and esophageal and pancreas cancer (3) and can also cause tooth stain, tooth loss, gum disease, lip and tongue cancer, gastric ulcer, depression, increased risk of cardiovascular diseases, premature birth, low birth weight, congenital iron deficiency anemia and infertility (3-10). Although the consumption of all tobacco products is addictive, the amount of nicotine absorbed from smokeless tobacco is three to four times more than that from cigarettes (11). In addition, nicotine remains longer in the blood of smokeless tobacco consumers compared to cigarette smokers (11). Given its shared border with Pakistan, these products are smuggled into Iran through Chabahar. Their cheap price, easy 
production and purchasing and families' lack of control, the misconceptions around their use ('smokeless tobacco has a therapeutic value; for instance, it helps heal toothache, headache, stomachache, etc.') and the very low awareness in teenagers and youth about their side effects have increased the use of smokeless tobacco products (12).

Guilds and merchants have always been known as part of the society that has a strong influence over and various functions in economic and social developments in different fields. In Iran, business guilds are crucial to the growth and dynamism of the economy as the last link in the economy chain, and act as the economic heart of the society through their extensive and direct contact with the public (13).

Reducing unhealthy behaviors, such as consuming smokeless tobacco, requires first the identification of the factors contributing to these behaviors. Some studies have examined the factors affecting smokeless tobacco use (14-17). Nonetheless, there are no studies on the predictive factors of smokeless tobacco use among Iranian business guilds. Different behavioral science theories and models are used to examine and understand tobacco use behaviors. The transtheoretical model (TTM) or the stages of change is one such model (18). Prochaska and DiClemente have proposed the TTM as an overall model of behavior change (19). This model assumes that behavior takes place in a series of steps and consists of four constructs, including the stages of change, the processes of change, self-efficacy and decisional balance (20). According to this model, people pass through five stages in order to change, including precontemplation, contemplation, preparation, action and maintenance. In the precontemplation stage, the individual does not want to change or adopt a healthy behavior within the next six months. In the contemplation stage, the individual thinks of a change in the next six months but is still not fully prepared for change. In the preparation stage, the individual is ready for change and prepares for starting a particular behavior. In the action stage, the individual has changed his behavior, but for a period less than six months. In the maintenance stage, the person has changed his behavior for more than six months (21). The TTM helps understand when people are ready to change (the stages of change), how they evaluate the advantages and disadvantages of tobacco use (decisional balance) and how, based on their beliefs and perceived self-efficacy, they overcome the tempting situations of tobacco use and stop using tobacco (perceived self-efficacy). The "processes of change" construct includes obvious and latent activities that people use to modify their behavior, and consists of ten processes divided into two classes, namely cognitive or empirical processes (self-liberation, consciousness-raising, environmental reevaluation, dramatic relief and selfreevaluation) and behavioral processes (counter-conditioning, social liberation, reinforcement management, stimulus control

17 | P a g e and helping relationships). In cognitive processes, the individual obtains information by himself, but in behavioral processes, he receives information from the environment (21). No studies have yet sought to investigate and understand smokeless tobacco use behaviors based on the TTM in Iran. Given the lack of research on this subject in Iran, the misconceptions among people and the adverse effects of the use of this psychoactive substance on people's environment, the present study was conducted to use the TTM to classify guild merchants using smokeless tobacco in Chabahar, Iran, and then analyze the relationships between the examined variables based on the constructs of this model.

\section{Materials and Method}

The present descriptive cross-sectional study was conducted on 320 merchants in Chabahar, Iran, in 2018. Given the 15\% prevalence of smokeless tobacco products as per the researchers' previous study (12), an alpha of $5 \%$ and an error rate of 0.04 , the sample size was calculated as 306, and 14 more were added in to compensate for attrition, which made for a final sample size of 320. Simple random sampling was used in this study. For this purpose, the researchers visited the Environmental and Occupational Health Department of the city's Health Center and used a health inquiry book to extract a list of eligible candidates for the study from 18 comprehensive urban and rural health service centers in Chabahar through simple random sampling. The data collection tool (i.e. the researcher-made questionnaire) was distributed among the participants to fill out. The inclusion criteria consisted of age 20 to 50 years, consenting to participate in the study, being able to answer the questionnaire items and having a business license in the Guilds Office. The exclusion criteria consisted of age below 20 and above 50, smoking (cigarettes, hookah, etc.) and belonging to a seasonal guild. The data collection tool was a researchermade questionnaire with three parts, including a demographic and background information section, a behavioral section and a TTM section (with items on the stages of change, processes of change, decisional balance, self-efficacy. temptation).

The demographic and background information section consisted of five items on age, gender, type of guild, level of education and marital status of the participants.

The behavioral section consisted of three items, which discussed the type of smokeless tobacco consumed, age at onset of use and daily frequency of consumption.

The TTM section contained items that were scored based on a 5-point Likert scale from 1 to 5, except for the stages of change construct. The stages of change construct had three items; the processes of change construct had 30 items (the scores ranged from 30 to 150 points), the decisional balance construct discussed the advantages and disadvantages of tobacco use and had 16 items (the scores ranged from 16 to 80 points) and

Website: https://www.banglajol.info/index.php/UpDCJ 
the self-efficacy construct had eight items (the scores ranged from 8 to 40 points).

The face validity of the questionnaire was assessed by surveying ten members of the panel of health education and promotion experts and a dentist. The Content Validity Ratio (CVR) and Content Validity Index (CVI) were used to determine the quantitative content validity of the questionnaire. The CVR and $\mathrm{CVI}$ of the behavioral items were calculated as 0.98 and 0.89 , and for the TTM items, these indexes were 0.88 and 0.95 . The Cronbach's alpha test was used to calculate the reliability of the questionnaire, which was 0.87 for the behavioral items and 0.81 for the TTM items. Data were analyzed in SPSS-16 using the mean and SD, the Chi-square test, the ANOVA and Tukey's test. The level of significance was set at $P<0.05$.

Findings:

Table 1. Participants' demographic and background information

\begin{tabular}{|c|c|c|c|c|}
\hline Variable & Group & $\begin{array}{l}\text { Numbe } \\
r\end{array}$ & $\begin{array}{l}\text { Percentag } \\
\text { e }\end{array}$ & P-Value \\
\hline \multirow[t]{3}{*}{ Age } & $20-30$ years & 221 & 69 & \multirow{3}{*}{$\begin{array}{l}\text { Chi-square } \\
=10.88 \\
\text { Df }=4 \\
P=0.028\end{array}$} \\
\hline & $30-40$ years & 77 & 24 & \\
\hline & $40-50$ years & 22 & 7 & \\
\hline \multirow[t]{3}{*}{ Gender } & Male & 202 & 63 & \multirow{3}{*}{$\begin{array}{l}\text { Chi-square } \\
=5.57 \\
\text { Df }=4 \\
P=0.234\end{array}$} \\
\hline & & & & \\
\hline & Female & 118 & 37 & \\
\hline \multirow[t]{10}{*}{ Guild } & Confectionery & 13 & 4 & \multirow{10}{*}{$\begin{array}{l}\text { Chi- } \\
\text { square }=29.9 \\
2 \\
D f=18 \\
P=0.038\end{array}$} \\
\hline & Textile store & 62 & 19 & \\
\hline & Grocery store & 46 & 15 & \\
\hline & Auto repair shop & 37 & 12 & \\
\hline & Hairdresser & 61 & 19 & \\
\hline & $\begin{array}{l}\text { Tailoring and } \\
\text { embroidery }\end{array}$ & 25 & 8 & \\
\hline & $\begin{array}{l}\text { Hotel and } \\
\text { restaurant }\end{array}$ & 7 & 2 & \\
\hline & Carpentry & 9 & 3 & \\
\hline & Wholesale & 33 & 10 & \\
\hline & $\begin{array}{l}\text { Other (goldsmith, } \\
\text { home appliance } \\
\text { seller and notions } \\
\text { shop) }\end{array}$ & 27 & 8 & \\
\hline \multirow{5}{*}{$\begin{array}{l}\text { Level of } \\
\text { Educatio } \\
n\end{array}$} & Illiterate & 51 & 16 & \multirow{5}{*}{$\begin{array}{l}\text { Chi- } \\
\text { square }=37.1 \\
4 \\
D f=14 \\
P=0.001\end{array}$} \\
\hline & $\begin{array}{l}\text { Reading and } \\
\text { writing }\end{array}$ & 35 & 11 & \\
\hline & Primary school & 55 & 17 & \\
\hline & Junior high school & 92 & 29 & \\
\hline & $\begin{array}{l}\text { High school and } \\
\text { above }\end{array}$ & 87 & 27 & \\
\hline \multirow{3}{*}{$\begin{array}{l}\text { Marital } \\
\text { Status }\end{array}$} & Single & 120 & 37.5 & \multirow[t]{3}{*}{-} \\
\hline & Married & 193 & 60.5 & \\
\hline & $\begin{array}{l}\text { Divorced.Widowe } \\
\text { d }\end{array}$ & 7 & 2 & \\
\hline
\end{tabular}

Table 1 shows the demographic characteristics of the participants. All the 320 merchants from different guilds participated in this study. Most of them were in the 20-30 age group (69\%). According to the Chi-square test, there was a significant relationship between the different age groups in terms of the stages of change $(\mathrm{P}=0.028)$.

18 | P a g e
A total of $63 \%$ of the subjects were male and $37 \%$ were female. According to the Chi-square test, there was no significant relationship between participants' gender and the stages of change $(P=0.234)$. Hairdressers and textile stores $(19 \%)$ comprised the largest guild participating in this study and hotel and restaurant business (2\%) comprised the smallest. According to the Chi- square test, there was a significant relationship between participants' guild type and the stages of change $(P=0.038)$. Most of the subjects had junior high school education only (29\%) and $16 \%$ were illiterate. The Chi-square test showed a significant relationship between participants' level of education and the stages of change $(P=0.001)$. In terms of marital status, the married .people $(60.5 \%)$ comprised the largest and the divorced. widowed people (2\%) the smallest groups in the study.

Table 2. The smokeless tobacco consumption behavior in the participants

\begin{tabular}{|c|c|c|c|}
\hline Variable & Group & Number & Percentage \\
\hline \multirow{9}{*}{$\begin{array}{l}\text { Type of smokeless } \\
\text { tobacco }\end{array}$} & Pan & 22 & 7 \\
\hline & Pan Parag & 73 & 23 \\
\hline & Gutkha & 76 & 24 \\
\hline & Naswar and BT & 68 & 21 \\
\hline & Mawa & 19 & 6 \\
\hline & Pan and Pan Parag & 10 & 3 \\
\hline & $\begin{array}{l}\text { Pan, Pan Parag, and } \\
\text { Gutkha }\end{array}$ & 16 & 5 \\
\hline & $\begin{array}{l}\text { Pan, Pan Parag, Gutkha, } \\
\text { Naswar and BT }\end{array}$ & 9 & 2.6 \\
\hline & All the types & 27 & 8.4 \\
\hline \multirow{3}{*}{$\begin{array}{l}\text { Age at the onset of } \\
\text { consumption }\end{array}$} & Less than 10 years old & 6 & 2 \\
\hline & 10 to 15 years old & 67 & 21 \\
\hline & 15 to 20 years old & 247 & 77 \\
\hline \multirow{2}{*}{$\begin{array}{l}\text { Daily frequency of } \\
\text { consumption }\end{array}$} & Less than 5 times & 206 & 64 \\
\hline & 5 to 10 times & 114 & 36 \\
\hline
\end{tabular}

Table 2 presents the status of smokeless tobacco use in the subjects. The participants used all the available types of smokeless tobacco products. Some of them used two or more products. Most consumed Gutkha (24\%) and Pan Parag (23\%), 68 (21\%) consumed Naswar and BT, $27(8.4 \%)$ consumed all the available types of smokeless tobacco products, and $22(7 \%)$ consumed Pan. As for age at the onset of consumption, only $2 \%$ of the participants had started using smokeless tobacco at an age below 10 , while $77 \%$ of the participants (i.e. the majority) had started using smokeless tobacco at an age between 15 and 20. A total of $64 \%$ of the participants consumed smokeless tobacco less than five times per day, and $36 \%$ used these products five to ten times per day.

Analyzing participants' perceived mean advantages and disadvantages of smokeless tobacco use based on the stages of behavior change (Table 3) showed that, as they advanced through the stages of change from precontemplation to preparation, the perceived advantages of tobacco consumption reduced significantly (Fig. 1, F=3.55, $\mathrm{P}=0.03$ ). Analyzing participants' perceived advantages of smokeless tobacco use based on the stages of change showed that the scores increased significantly as the subjects advanced through the stages of change from precontemplation to preparation (Fig. 2, $\mathrm{F}=7.50, \mathrm{P}=0.001$ ).

Website: https://www.banglajol.info/index.php/UpDCJ 
Table 3. A comparison of the mean and standard deviation of the processes of change in smokeless tobacco consumption behaviors and the stages of change in business guilds consuming smokeless tobacco products

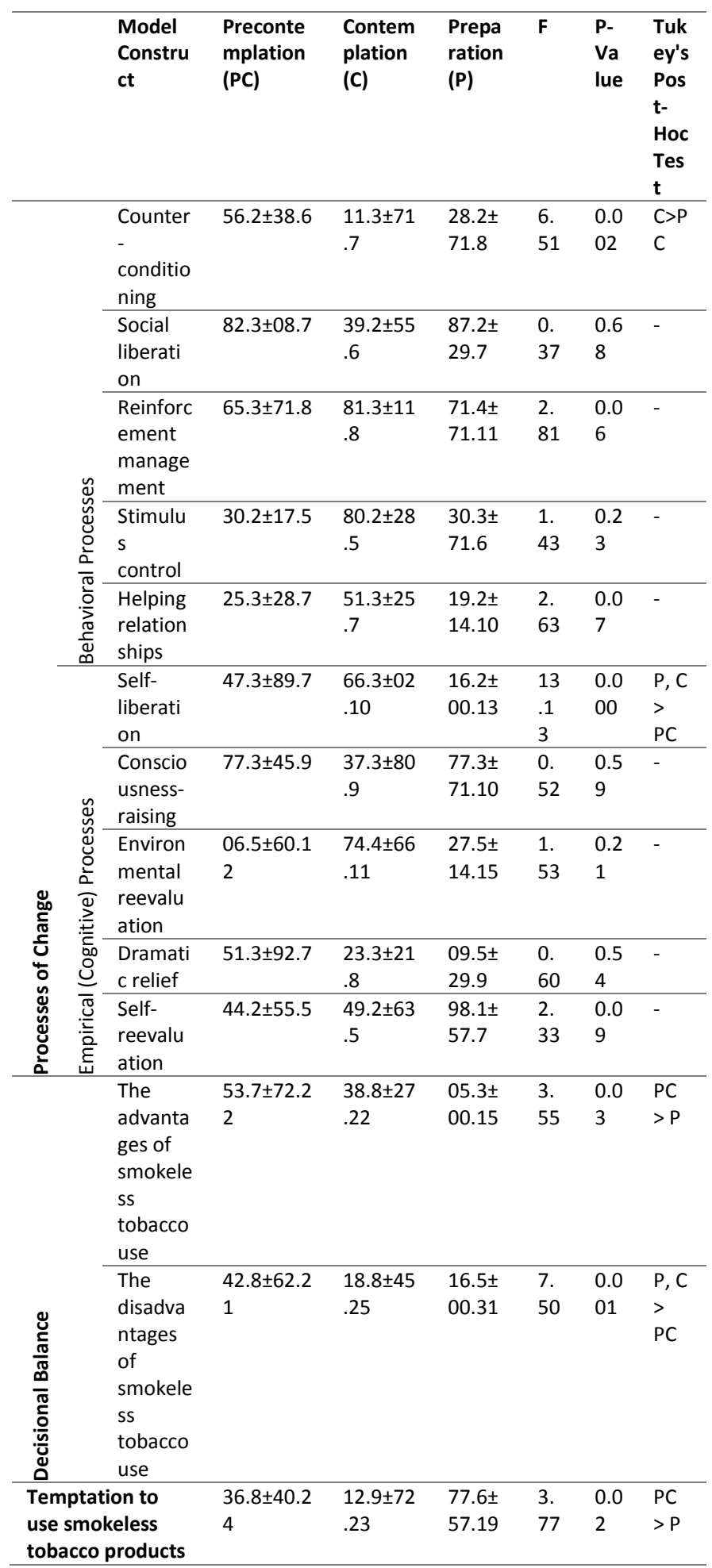

19 | P a g e
As for the processes of change construct, the ANOVA showed that there is a significant relationship between some of these processes and the stages of change in smokeless tobacco use behaviors. Tukey's test showed that, of the processes of behavior change, only the counter-conditioning process has a significant relationship with the stages of change in tobacco consumption behaviors ( $\mathrm{F}=6.51, \mathrm{P}=0.002)$, and there was no significant relationship with the rest of the processes in this class. In the empirical processes of behavior change, only the self-liberation process had a significant relationship with the stages of behavior change ( $\mathrm{F}=13.13, \mathrm{P}=0.000)$, and there was no significant relationship with the rest of the processes in this class.

Also, with the advancement of the participants from precontemplation to preparation, the level of self-efficacy increased and their temptation to consume tobacco decreased (Fig. 3) and a significant relationship was observed between the temptation to use tobacco and the stages of behavior change $(F=3.77, P=0.02)$.

Table 4. The frequency of the stages of change in smokeless tobacco users

\begin{tabular}{llllll}
\hline \multicolumn{2}{l}{ Precontemplation } & \multicolumn{2}{l}{ Contemplation } & \multicolumn{2}{l}{ Preparation } \\
\hline Numbe & Percentag & Numbe & Percentag & Numbe & Percentag \\
$\mathbf{r}$ & $\mathrm{e}$ & $\mathrm{r}$ & $\mathrm{e}$ & $\mathrm{r}$ & $\mathrm{e}$ \\
\hline $\mathbf{2 7 2}$ & 85 & 40 & 12.5 & 7 & 2.5 \\
\hline
\end{tabular}

Table 4 presents the frequency of the stages of change in smokeless tobacco users. A total of 272 subjects (85\%) were in the precontemplation stage, 40 $(12.50 \%)$ were in the contemplation stage and seven $(2.5 \%)$ were in the preparation stage. In other words, most of the participants were in the precontemplation stage.

Figure 1. The relationship between the advantages of smokeless tobacco consumption and the stages of change in Chabahar guild merchants

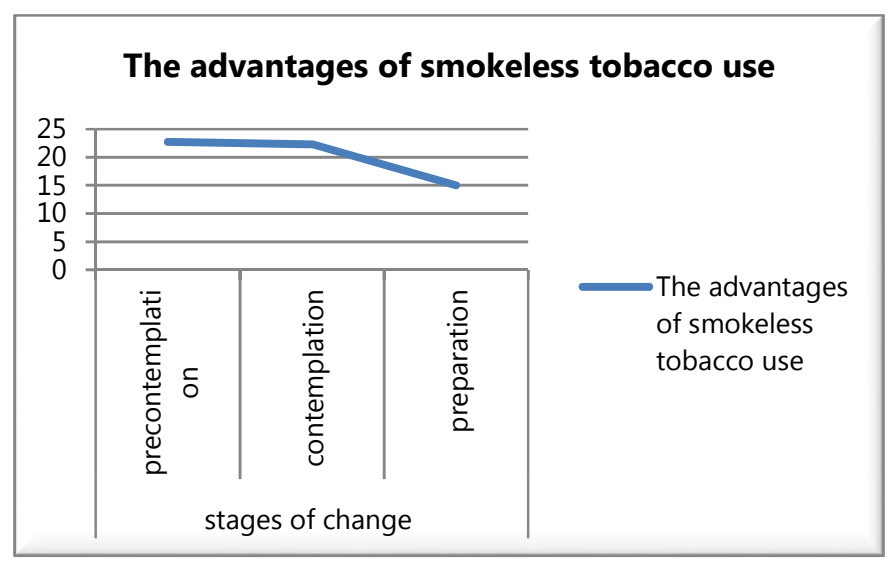


Figure 3. The relationship between the temptation to use smokeless tobacco and the stages of change in Chabahar guild merchants

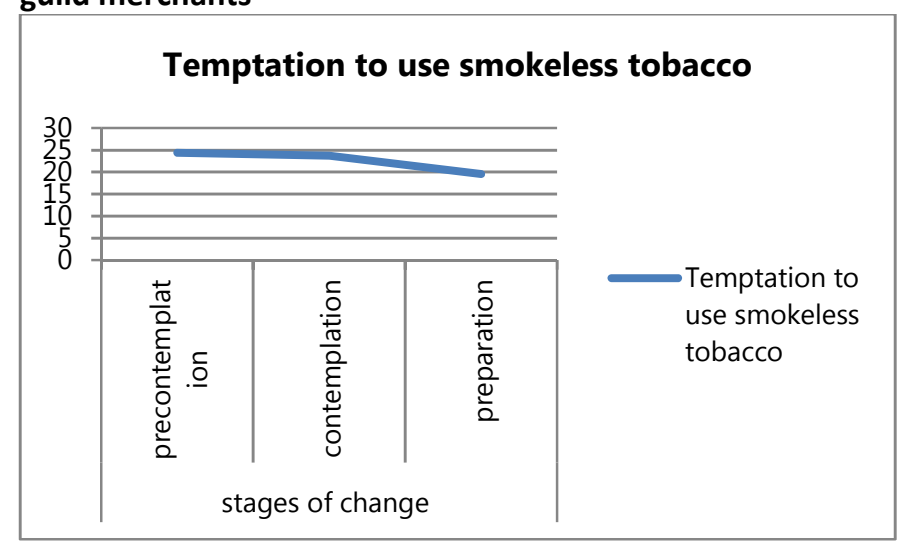

Discussion and Conclusion

The present study was conducted to classify guild merchants consuming smokeless tobacco in Chabahar, Iran, based on the TTM and analyze the relationships between the examined variables based on the constructs of this model. The results showed that the predominant form of smokeless tobacco consumed in the study population is Gutkha. The easy access to its constituent materials, low cost, entry to the country from Pakistan border by smuggling and traditional procurement, preparation and packaging with different brands in Chabahar can justify the high consumption of this type of smokeless tobacco product in the examined merchants. The traditional packaging of Gutkha without any health warnings is yet another reason to use this product. In a study by Sein et al. (22), the low price of smokeless tobacco products, the easy access, and the weaknesses in the enforcement of the tobacco control law have been the main challenges with regard to the use of smokeless tobacco in Myanmar, which appear almost similar to the reasons discussed in the present study. The most dominant form of smokeless tobacco was Mawa in the study by Rose et al. (23) and Naswar in the study by Desalu et al. (5). This disparity of findings may be due to the differences in age group and cultural and social context between the two studies' populations.

In this study, most participants had started using smokeless tobacco from the age of 15-20. In the study by Muttappallymyalil et al. (8), the age at the onset of smokeless tobacco consumption was less than 12 . In the study by Narain et al. (24), the age at the onset of smokeless tobacco consumption was 12 to 13 . These disparities can be justified by noting that the population studied in the two aforementioned studies was comprised of only students while the subjects in the present study were from all classes of the society and also

20 | P a g e by noting the differences in the social context of the two communities in question.

In the study by Mishra et al. (25), the age at the onset of smokeless tobacco consumption was 20 to 30, which is different from the present study. In this study, $64 \%$ of the subjects used smokeless tobacco fewer than five times per day. In studies by Al Agili et al. (26) and Mishra et al. (25), the participants used smokeless tobacco six and two-four times per day, respectively, which is almost the same as the present findings.

In view of the TTM constructs, most of the participants (85\%) were in the precontemplation stage and were not thinking of quitting smokeless tobacco. Given the well-known harms of tobacco and the low mean age of the participants, proper interventions to encourage and motivate users to quit tobacco are necessary. Various studies have proven the effectiveness of this model in successful smoking cessation (27-29). Nevertheless, the stages of change in smokeless tobacco consumption behaviors vary in different populations and countries and based on the sampling method used. In two studies by Wanger, $85 \%$ and $79 \%$ of the participants were in the preparation stage (30 and 31 ), which is not consistent with the present findings. This disparity could be because the samples were selected from people who had voluntarily presented to a military smoking cessation clinic. In a study by Anja in Germany (32) and a study by Tavafian in Bandar Abbas (33), the distribution of the subjects in the different stages of change was not consistent with that reported in the present study. This disparity could be due to the differences in sampling method and study population. The mean score of the advantages of smokeless tobacco consumption decreased significantly from the precontemplation to the preparation stage. It appears that the advantages of tobacco use are more highlighted to people in the preparation stage because of their high temptation to use. In a study by Alkar, the advantages of smoking decreased significantly from the precontemplation to the contemplation and preparation stages (34), which is consistent with the present study. The mean score of the disadvantages of smokeless tobacco consumption also increased significantly from the precontemplation to the preparation stages. These results are consistent with those reported by Alkar, in which the disadvantages of smoking increased significantly throughout the stages (34).

The use of cognitive or empirical processes during the stages of change did not have a significant relationship except with the "self-liberation" construct, which indicates that people believe in the possibility of change when they decide to cease tobacco use. The distribution of the majority of the guild merchants in the precontemplation and contemplation stages can justify this finding. Also, of all the behavioral processes, only the counter-conditioning construct had a significant relationship with the stages of change, which reflects how, at

Website: https://www.banglajol.info/index.php/UpDCJ 
this stage, people need to learn new behaviors instead of their old unhealthy behaviors. In other words, if appropriate interventions are developed in this stage based on the constructs of the TTM, they can lead people to further stages of change and ultimately help them decrease their use of smokeless tobacco. Sharifirad et al. (35) also reported a significant relationship between the "counter-conditioning" construct of behavioral processes and the stages of behavior change, which is consistent with the results of the present study in this section. Nonetheless, their results were not consistent with the present study in the case of cognitive or empirical processes, perhaps due to the differences in sampling method and study population.

The self-efficacy construct increased significantly in order to overcome the tempting conditions of tobacco use, and in contrast, the tempting cases of tobacco use reduced. This finding is consistent with the assumptions of the TTM. Other studies have also reported an increase in self-efficacy throughout the stages of change from precontemplation to preparation, and this increase requires an increased selfesteem for overcoming the tempting situations calling for tobacco use $(36,37)$. This finding reflects the fact that the selfefficacy construct is the key to a successful cessation of tobacco use, and on that basis, the tempting cases of tobacco use can be identified in guild merchants to be addressed and resolved.

One of the limitations of this study is its use of a questionnaire, which might have affected the assessment of the actual views of the participants; the generalization of the results should therefore be carried out with caution. Similar studies in different guilds and different age, socio-economic and ethnic groups can also help obtain more realistic results.

\section{Conclusions:}

Most guild merchants examined in this study were in the precontemplation stage, and given their age and the proven harms of smokeless tobacco, interventions based on the constructs of the TTM are necessary to encourage this group to quit tobacco use.

\section{Acknowledgement:}

This paper was extracted from a PhD dissertation on Health Education and Promotion by the Corresponding author and has been funded by the Research Deputy of Shahid Sadoughi University of Medical Sciences in Yazd (Ethics Code: IR.SSU.SPH.REC.1396.105). Hereby, the authors wish to express their gratitude to the research experts of Shahid Sadoughi University of Medical Sciences in Yazd, the Research Deputy of Zahedan University of Medical Sciences, Chabahar Chamber of Guilds and the participating merchants.

21 I P a g e

\section{References:}

1. Banerjee SC, Ostroff JS, Bari S, D'Agostino TA, Khera M, Acharya S, et al. Gutka and Tambaku paan use among South Asian immigrants: a focus group study. J Immigr Minor Health. 2014; 16:531-539.

https://doi.org/10.1007/s10903-013-9826-4

PMid:23579964 PMCid:PMC4097304

2. Lee PN, Hamling J. Systematic review of the relation between smokeless tobacco and cancer in Europe and North America. BMC Med. 2009; 7:36-7015. https://doi.org/10.1186/1741-7015-7-36

PMid:19638245 PMCid:PMC2744672

3. Hussain J, Ram S. Prevalence of tobacco habits and attitude towards its cessation among outpatients of Mahatma Gandhi Missions Dental College and Hospital, Navi Mumbai, Maharashtra. J Contemp Dent 2013; 3 (2):57-60. https://doi.org/10.5005/ip-journals-10031-1037

4. Ahmed HG. Aetiology of oral cancer in the Sudan. J Oral Maxillofac Res. 2013; 4(2):e3. https://doi.org/10.5037/jomr.2013.4203

5. Desalu O O, Iseh K R, Olokoba A B, Salawu F K, Danburam A. Smokeless tobacco use in adult Nigerian population. Nigerian journal of clinical practice. 2010:13. 382-7.

6. Piano MR, Benowitz NL, FitzGerald GA, Corbridge S, Heath J, Hahn E, et al. Impact of Smokeless Tobacco Products on Cardiovascular Disease: Implications for Policy, Prevention, and Treatment. Circulation. 2010; 122 (15):15-20. https://doi.org/10.1161/CIR.0b013e3181f432c3

PMid:20837898

7. Nargis N, Hussain A, Fong G. Smokeless tobacco product prices and taxation in Bangladesh: Findings from the ITC survey. Indian journal of cancer. 2014; 51(1): 33-38.

8. Muttapppallymyalil J, Sreedharan J, Divakaran B. Smokeless tobacco consumption among school children. Indian J Cancer. 2010; 47: 19-23. https://doi.org/10.4103/0019-509X.63872 PMid:20622409

9. Nemeth JM, Liu ST, Klein EG, Ferketich AK, Kwan M-P, Wewers ME. Factors Influencing Smokeless Tobacco Use in Rural Ohio Appalachia. Journal of community health. 2012; 37 (6):1208-1217.

https://doi.org/10.1007/s10900-012-9556-x

PMid:22427033 PMCid:PMC4298853

10. Hossain MS, Kypri K, Rahman B, Arslan I, Akter S, Milton AH. Prevalence and Correlates of Smokeless Tobacco Consumption among Married Women in Rural Bangladesh. Sun Q, ed. PLoS ONE. 2014; 9 (1): 1-6. https://doi.org/10.1371/journal.pone.0084470

11. National Institutes of Health, National Institute on Drug Abuse. (2009). Smokeless tobacco (Topics in Brief). Retrieved from http...www.drugabuse.gov.publications.topics-in-brief.smokeless-tobacco 12. Jalilvand M, Nikmanesh Z, Kazemi Y, et al. Smokeless Tobacco Use among University Students: A Cross-Sectional Study in Sistan Baloochestan Province, Iran. Iranian Journal of Psychiatry and Behavioral Sciences. 2008; 4, (1): 23-29. 13. http:..otaghasnafeiran.ir.

14. Nemeth, Julianna M., Sherry T. Liu, Elizabeth G. Klein, Amy K. Ferketich, Mei-Po Kwan and Mary Ellen Wewers. "Factors Influencing Smokeless Tobacco Use in Rural Ohio Appalachia." Journal of Community Health 37 (2012): 12081217. https://doi.org/10.1007/s10900-012-9556-x

15. Etu E., Gemeda D., Hussen M. Prevalence and factors that influence smokeless tobacco use among adults in pastoralist communities of Borena zone, Ethiopia: mixed method study. Tobacco Induced Diseases. 2018; 16 (1): 263. https://doi.org/10.18332/tid/84119

https://doi.org/10.18332/tid/84104

16. Kerstin K. Rauwolf, Kristina J. Berglund, Ulf Berggren, Jan Balldin, Claudia Fahlke; The Influence of Smoking and Smokeless Tobacco on the Progression, Severity and Treatment Outcome in Alcohol-Dependent Individuals, Alcohol and Alcoholism; 2017, 52 (4): 477-482

https://doi.org/10.1093/alcalc/agx031

17. Singh JK, Acharya D, Kadel R, Adhikari S, Lombard D, Koirala S, et al. Factors Associated with Smokeless Tobacco Use among Pregnant Women in Rural Areas of the Southern Terai, Nepal. J Nepal Health Res Counc. 2017; 15 (35):1219. https://doi.org/10.3126/jnhrc.v15i1.18007 PMid:28714486

Website: https://www.banglajol.info/index.php/UpDCJ 
18. Prochaska JO DC. Stage and processes of self-change of smoking: Toward and integrative model. Consult Clin Psychol. 1983; 51 (3): 390-5. https://doi.org/10.1037/0022-006X.51.3.390

19. Coulson N, Buchanan H. Student attendance at dental checkups: An application of the Transtheoretical Model. Health Education Journal. 2002; 61(4): 309-19. https://doi.org/10.1177/001789690206100404

20. Prochaska JO. Transtheoretical model of behavior change. Encyclopedia of behavioral medicine: Springer; 2013: 1997-2000.

21. Bartholomew LK, Parcel GS, Kok G, Gottlieb NH. Planning health promotion programs: an intervention mapping approach: John Wiley \& Sons; 2011.

22. Sein T, Swe T, Toe M M, Zaw K K, Sein T O. Challenges of smokeless tobacco use in Myanmar. Indian J Cancer 2014; 51, Suppl S1:3-7

23. Rose ML, Chadha D, Bhutia TD. Smokeless tobacco use and perceptions of risk among students in Mumbai municipal schools. Indian J Cancer 2016; 53:322-4. https://doi.org/10.4103/0019-509X.197720 PMid:28071638

24. Narain R, Sardana S, Gupta S, Sehgal A. Age at initiation \& prevalence of tobacco use among school children in Noida, India: A cross-sectional questionnaire based survey. The Indian Journal of Medical Research. 2011;133 (3):300-307

25. Mishra GA, Kulkarni SV, Gupta SD, Shastri SS. Smokeless tobacco use in Urban Indian women: Prevalence and predictors. Indian J Med Paediatr Oncol 2015; 36:176-82. https://doi.org/10.4103/0971-5851.166739

PMid:26681842 PMCid:PMC4672461

26. Al Agili, D.E., Park, H.K. Oral health status of male adolescent smokeless tobacco users in Saudi Arabia. EMHJ - Eastern Mediterranean Health Journal. 2013; 19 (8), 711 - 719. https://doi.org/10.26719/2013.19.8.711

27. Aveyard P, Massey L, Parson A, Manaseki S, Griffin C. the effect of Transtheoretical Model based interventions on smoking cessation. Social Science \& Medicine. 2009; 68: 397-403.

https://doi.org/10.1016/j.socscimed.2008.10.036

PMid:19038483

28. Erol S, Erdogan S. Application of a stage based motivational interviewing approach to adolescent smoking cessation: The Transtheoretical Model-based study. Patient Education and Counseling. 2008; 72: 42-48. https://doi.org/10.1016/j.pec.2008.01.011 PMid:18304775

29. Aveyard P, Sherratt E, Almond J, Lawrence T, Lancashire R, GriffinC, et al. The Change-in-Stage and Updated Smoking Status Results from a ClusterRandomized Trial of Smoking Prevention and Cessation Using the Transtheoretical Model among British Adolescent. Preventive Medicine. 2001; 33: 313-324. https://doi.org/10.1006/pmed.2001.0889

PMid:11570836

30. Wagner J, Sirois B, Burg M. Social support and the transtheoretical model: Relationship of social support to smoking cessation stage, decisional balance, process use, and temptation. Adictive Behaviors. 2004; 29 :1039-1043 https://doi.org/10.1016/j.addbeh.2004.02.058 PMid:15219355

31. Wagner J, Heapy A, Frantsve L, Abbott G, Burg M. Transtheoretical model constructs in smokers with and without medical illness: A second look the medical effect. Addictive Behaviors. 2006; 31: 1283-1289. https://doi.org/10.1016/j.addbeh.2005.09.003 PMid:16242245

32. Schumann A, John U, Rumpf H, Hapke U, Meyer C.Changes in the "stages of change" as outcome measures of a smoking cessation intervention: A randomized controlled trial. Preventive Medicine. 2006; 43:101-106. https://doi.org/10.1016/j.ypmed.2006.04.003 PMid:16709427

33. Tavafian S, Aghamolaei T, zare SH. Distribution of smokers by stages of change of smoking: a population based study from BndarAbbass, Iran. Payesh, Journal of the Iranian Institute for Health Sciences Research 2009; 3 (8): 263269 [Persian].

34. Yalçinkaya-Alkar O, Karanci N. What are the differences in decisional balance and self-efficacy between Turkish smokers in different stages of change? Addictive Behaviors. 2007; 32: 836-849.

https://doi.org/10.1016/i.addbeh.2006.06.023

35. Sharifirad G. R, Charkazi A, Mansourian M. Categorizing and analysis of Smoking based on transtheoretical models among Male Students of Isfahan Medical Sciences and Isfahan University. j.health. 2011; 2 (1) :56-65

22 | $\mathrm{P}$ a g $\mathrm{e}$
36. Fagan, P, Eisenberg M, Frazier L, Stoddard A.M, Avrunin J.S, Sorensen G. Employed adolescents and beliefs about self-efficacy to avoid smoking. Addictive Behaviors. 2002; 27:1-14.

37. Segan C.J, Borland R, Greenwood K.M. Do transtheoretical model measures predict the transition from preparation to action in smoking cessation? Psychology and Health. 2002; 17: 417-435. https://doi.org/10.1080/0887044022000004911 